\title{
Synovial Sarcoma Involving the Median Nerve: A Case Report
}

\section{Median Sinir Tutulumu Gösteren Sinoviyal Sarkom: Bir Olgu Sunumu}

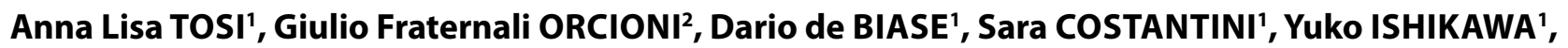 \\ Vincenzo EUSEBI ${ }^{1}$ \\ 'University of Bologna, Bellaria Hospital, Section of Anatomic Pathology "M. Malpighi", BOLOGNA, ITALY \\ ${ }^{2}$ IRCCS AOU San Martino-IST, National Institute for Cancer Research, Unit of Anatomic Pathology, GENOVA, ITALY
}

\begin{abstract}
Synovial sarcoma may arise from different and unusual sites. Here a case of biphasic synovial sarcoma arising or invading the radial nerve in a 59-year-old female classically showing chromosomal reciprocal translocation $(\mathrm{X} ; 18)$ is reported. The differential diagnosis from similar tumors is discussed.
\end{abstract}

Key Words: Synovial sarcoma, Sarcoma, Soft tissue tumor, Nerve, Forearm

\section{INTRODUCTION}

Synovial sarcoma has distinctive morphological and genetic features (1). It is mostly prevalent in the extremities of adolescents and young adults. Occasionally it has been reported in unusual sites such as heart, lung, small intestine, soft palate, retro-peritoneum and 22 cases have also been reported in peripheral nerves (2-10).

Here a case of biphasic synovial sarcoma of the median nerve of the right arm in a 59-year-old woman is reported, together with evidence of chromosomal reciprocal translocation $\mathrm{t}(\mathrm{X} ; 18)$.

\section{CASE REPORT}

In December 2010, a 59-year-old female not showing von Recklinghausen syndrome was admitted to Ospedale San Martino, Genova, Italy, having a palpable nodule located in the soft tissue of the right forearm. Magnetic resonance imaging (MRI) showed that the lesion was located between the flexor muscles and the radial diaphysis and was strictly adherent to the median nerve and ulnar artery (Figure 1). In January 2011, the nodule was excised. No recurrent tumour was evident at a second MRI obtained in August 2011. No other lesions in other organs were

(Turk Patoloji Derg 2012, 28:266-269)

Received : 22.12.2011 Accepted : 18.02.2012

\section{ÖZ}

Sinovyal sarkom çok farklı ve beklenmedik dokulardan kaynaklanabilir. Burada kromozomal resiprokal translokasyonu (X; 18) gösterilmiş olan 59 yaşındaki kadın hastada sinir kaynaklı bifazik sinovyal sarkom olgusu sunulmaktadır. Benzer tümörlerin ayırıcı tanısı tartışılmaktadır.

Anahtar Sözcükler: Sinovyal sarkom, Sarkom, Yumuşak doku tümörleri, Sinir, Önkol

evidenced after a total body computerised tomography scans. The patient was in good health when last seen in December 2011. For treatment, radiation therapy was not administered on first instance as the tumor was well circumscribed and it was considered completely excised.

Tissue processed as routine was fixed in $10 \%$ buffered formalin, embedded in paraffin and stained with Haematoxylin and Eosin (H\&E). Periodic Acid-Schiff stain (PAS) without diastase pre-digestion was obtained. Immunostaining was performed on $3 \mu \mathrm{m}$ sections using Ventana system (Ventana, Benchmark, Tucson, Arizona). The following prediluted Ventana antibodies were employed: TTF-1, ER, EMA, S100, CK 7, and MNF 116. A tissue block was selected for RNA extraction. SS18-SSX synovial sarcoma fusion transcripts analysis was performed on three sections $20 \mu \mathrm{m}$-thick from paraffin embedded tissue block. RNA was extracted using the RecoverAll kit (Ambion Inc., Austin, Texas, USA) in accordance to the manufacturer's instruction. RNA concentration was measured using Quant-it ${ }^{\mathrm{TM}}$ RNA kit (Invitrogen, Carlsbad, California). Reverse-transcription PCR was performed using the Transcriptor High Fidelity cDNA Synthesis Sample Kit (Roche Diagnostic, Mannheim, Germany).

Correspondence: Anna Lisa TOSI

University of Bologna, Bellaria Hospital, Section of Anatomic Pathology

"M. Malpighi", BOLOGNA, ITALY

E-mail: annalisa.tosi3@unibo.it Phone: +390516225523 
Rearrangements SS18-SSX1, SS18-SSX2, SS18-SSX4 were analysed using previously described primers (11). Quantitative polymerase chain reaction amplification (qRT-PCR) was performed using the Real-Time ABI PRISM 7000 (Applied Biosystems, Foster city, CA). Reactions were run in double. Beta-Actin and Beta-2-Microglobulin were used as house-keeping genes.

Macroscopically, the nodule had smooth circumscribed

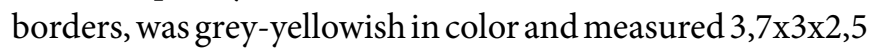
$\mathrm{cm}$. Histologically the tumour was well circumscribed and surrounded by a dense sclero-hyaline capsule (Figure 2). The lesion was constituted of numerous glands. These were

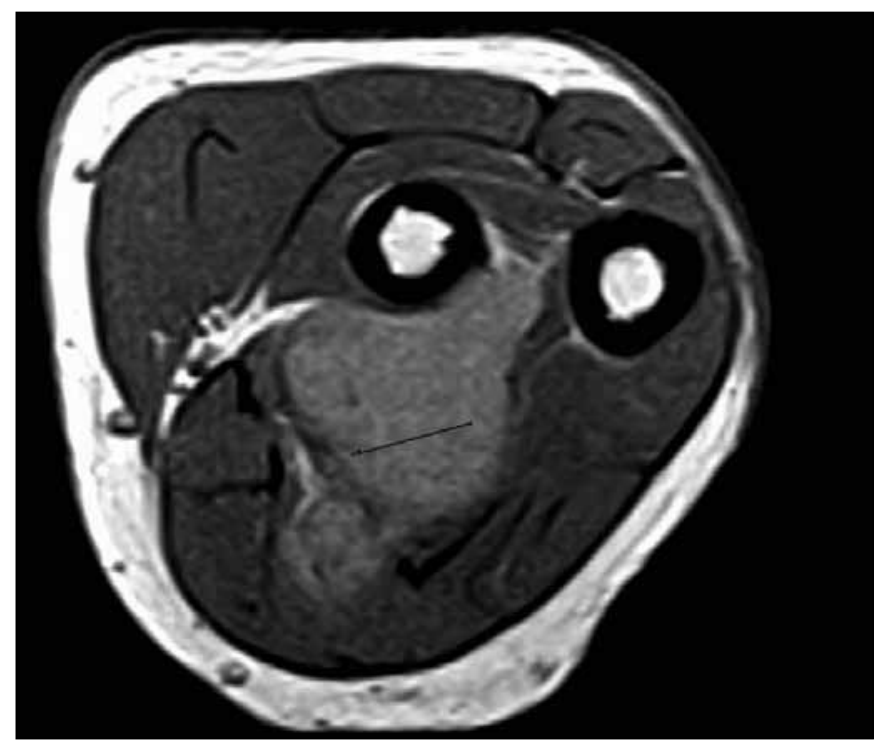

Figure 1: MRI: The lesion is located between the flexor muscles and the radial diaphysis and adherent to the median nerve (arrow) and ulnar artery. lined by one layer of cuboidal to columnar cells showing eosinophilic cytoplasm and round to ovoid nuclei with a single small nucleolus. Lumina were round to irregular and their calibre varied from small to medium large. Their content was composed of dense eosinophilic strongly PAS positive material (Figure 3A, B). Glands were immersed within tightly packed spindle cells with nuclei similar to those of the glandular structures (Figure 4). Mitoses were scanty and averaged 1 to 2 per 10 HPF (x400). Necrosis was absent. EMA strongly stained most of the glandular elements. Spindle cells were occasionally EMA positive. The dense luminal content was also strongly positive. MNF 116

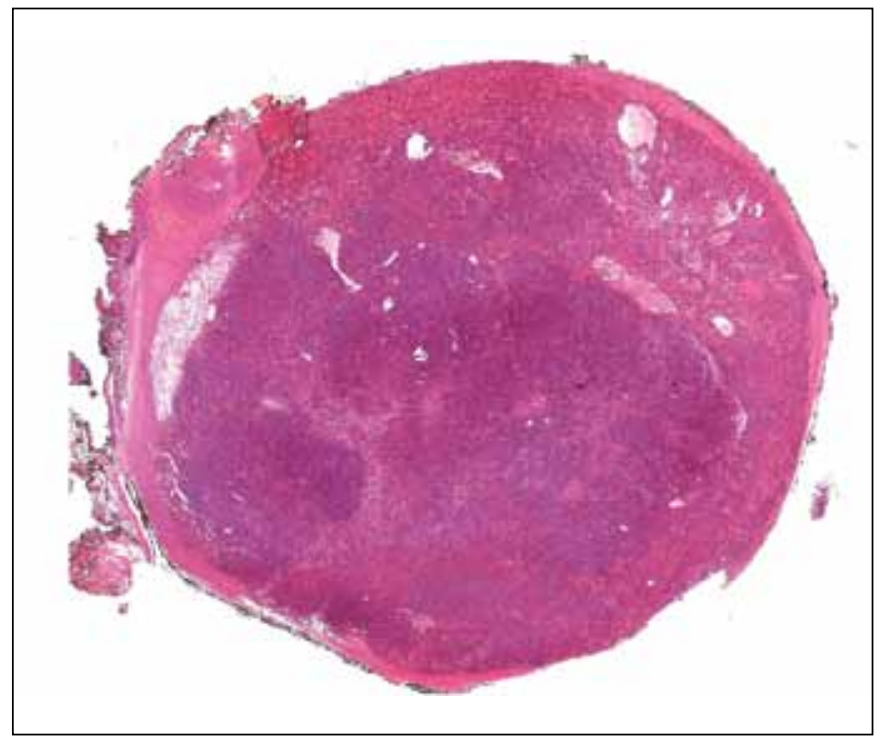

Figure 2: A thick sclero-hyaline capsule completely surrounds the lesion (H\&E, $\mathrm{x} 2)$.

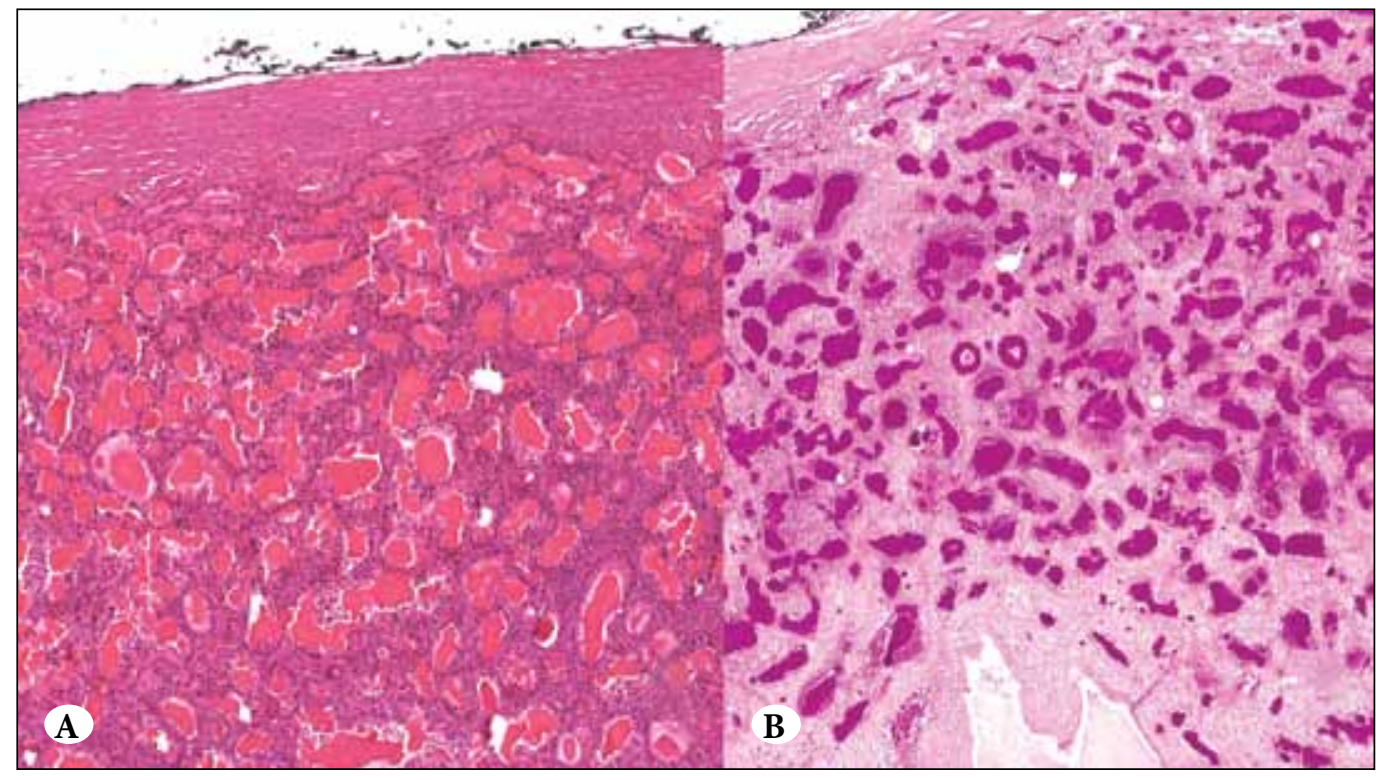

Figure 3: (A) Numerous glands have lumina filled (H\&E, x5), (B) with dense eosinophilic PAS positive material (x5). 
decorated most of the glands (Figure 5A) while cytokeratin 7 stained occasional glands and rare spindle stromal cells. ER, TTF-1, and S-100 protein were consistently negative. Occasional elongated spindle cells with bland, small, central nuclei were entrapped within the sclerotic capsule. These

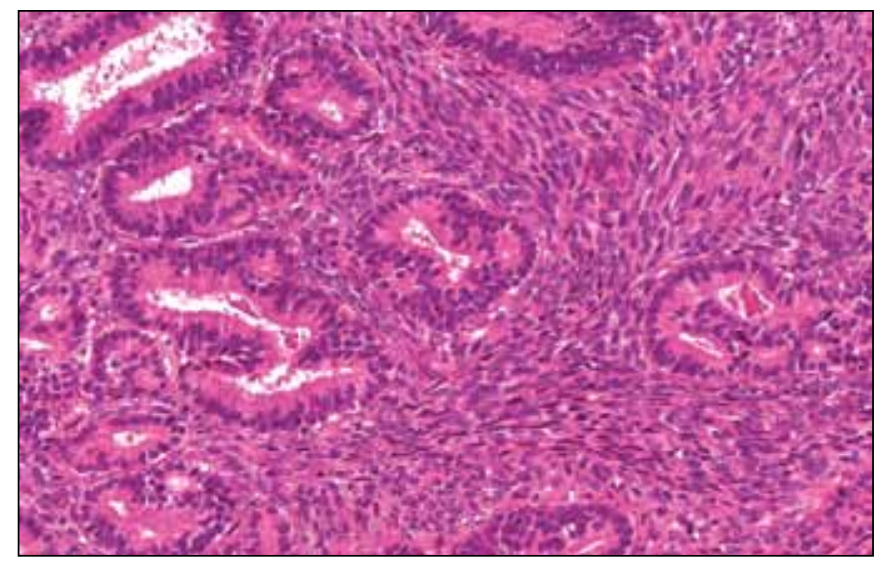

Figure 4: Glands were lined by columnar cells and were immersed within tightly packed spindle "stromal" cells. The nuclei of both components were similar ( $\mathrm{H} \& \mathrm{E}, \mathrm{x} 20)$.
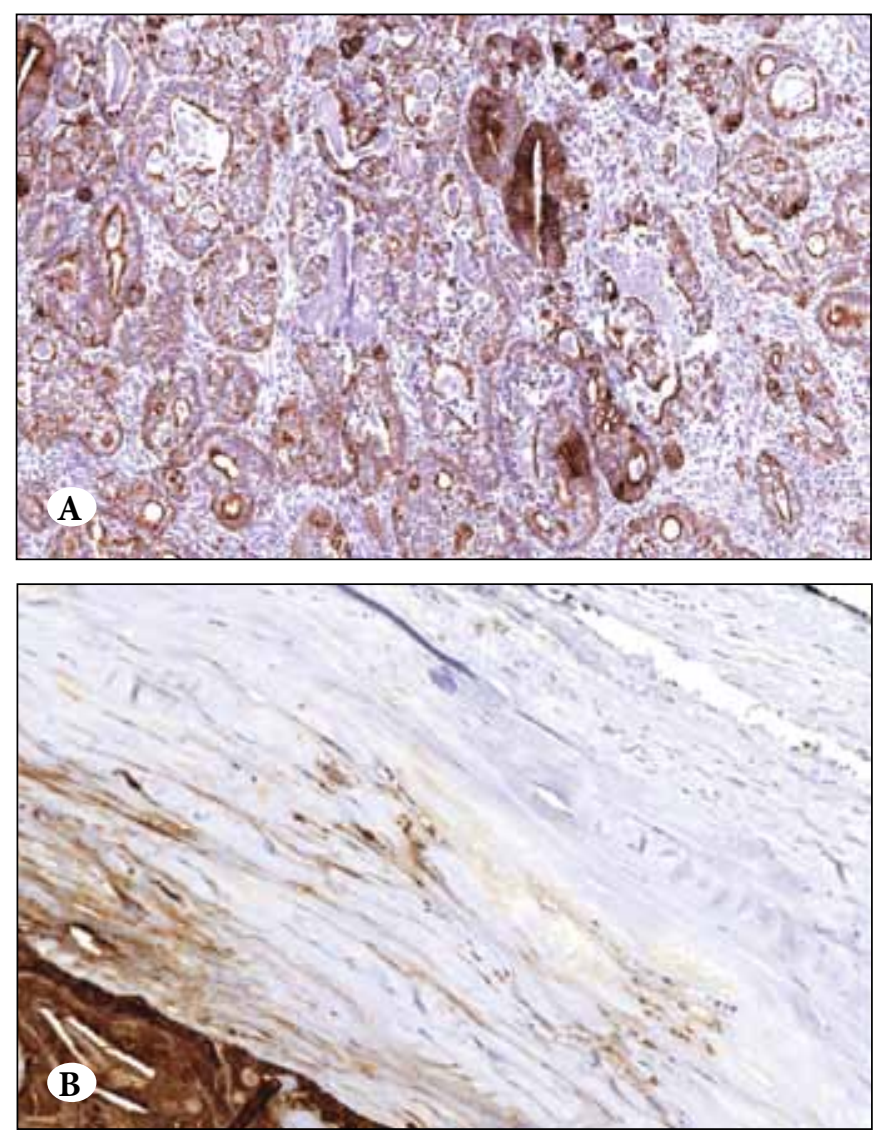

Figure 5: (A) Most of the glands were immunoreactive for cytokeratin (MNF 116, x10); (B) Elongated spindle EMA positive cells were located within the thick capsule. These cells are consistent with perineural elements (x20). same cells consistently stained for EMA and were negative for cytokeratins (Figure 5B).

In this neoplasm molecular analysis gave a positive signal for SS18-SSX1 transcript, while no positivity was observed for SS18-SSX2 and SS18-SSX4 rearrangements (Figure 6A, B).

\section{DISCUSSION}

The present case was regarded as a biphasic synovial sarcoma as it was characterized by a neoplastic proliferation showing at the same time glands as well as "stromal" spindle elements. These were both immunoreactive at varying extent for cytokeratins and EMA. The neoplastic proliferation had also the characteristic SS18-SSX1 chromosomal fusion at molecular level, a feature also consistent with the diagnosis of synovial sarcoma (12). The lesion was shown to be located adherent to a branch of median nerve of the right forearm as evidenced by MRI at such degree that it was difficult to state if the lesion had arisen within the nerve or was invading it. Nevertheless the evidence of a thick fibrous capsule that surrounded the neoplastic proliferation indicated a pre-existing structure. This was also suggested by the presence within the capsule of numerous elongated EMA positive and cytokeratin negative cells with bland nuclei that were very reminiscent of perineural cells. Synovial sarcomas classically are seen in limbs, but other locations are occasionally seen such as heart, lung, small intestine, soft palate, and retro-peritoneum. Peripheral nerves have been shown to be site of origin of this neoplasm, as reported in 22 instances (8).

The present tumour had to be distinguished from a glandular malignant peripheral nerve sheath tumour (MPNST), which also shows glandular proliferation within a malignant tumor of nerves $(1,13,14)$. At the variance with the present lesion, MPNST occur in patients with neurofibromatosis type I and arise in the background of a plexiform neurofibroma. Histologically, the glands of

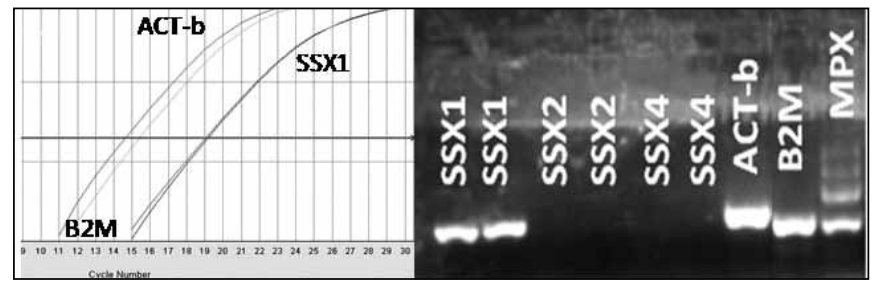

Figure 6: The positivity for SS18-SSX1 transcript is shown by (A) qRT-PCR and (B) the corresponding agarose gel. (SSX1: SS18SSX1 rearrangement; SSX2: SS18-SSX2 rearrangement; SSX4: SS18-SSX4 rearrangement; ACT-b: Beta-Actin; B2M: Beta-2microglobulin; MPX: multiplex PCR, amplifying 100-200-300$400 \mathrm{bp}$, used as molecular weight.) 
biphasic synovial sarcomas tend to be small and filled with eosinophilic PAS positive luminal content in contrast to the enteric-type glands seen in MPNST showing glandular differentiation (13). In addition, MPNST with glandular differentiation show S100 positive and keratin and EMA negative spindle cells. In contrast, the spindle cells of biphasic synovial sarcoma are strongly positive for EMA and usually negative for S-100 (12). Molecular studies are also helpful in distinguishing the two neoplasms. The SS18SSX fusion gene transcript, as detected with conventional RT-PCR and qRT-PCR, is seen in more than $90 \%$ of cases of synovial sarcoma (11). The SS18-SSX1 is most frequently associated with biphasic synovial sarcoma (15). Molecular markers of MPNST instead include NF1 and p16 deletions as well as epidermal growth factor receptor amplification and polysomes for either chromosome 7 or 22 (16). Metastatic biphasic sarcomatoid carcinoma was also taken in consideration. Metastatic lung, breast carcinomas were excluded by negative TTF- 1 and ER immunostaining as well as lack of any clinical sign. The histology, the immunohistochemical findings, together with the evidence of fusion transcript of SS18-SSX1 led to the diagnosis of biphasic synovial sarcoma. Although MRI was equivocal in establishing the exact site of origin of the tumor, the existence of a capsule containing perineurial cells were probative for an origin of the lesion from a nerve.

In conclusion aim of the present paper was that to report a synovial sarcoma of the nerve that in spite of the several cases described is still not a well-known neoplasm.

\section{REFERENCES}

1. Weiss SW, Goldblum JR: Enzinger's and Weiss's Soft Tissue Tumors. 5th ed., Philadelphia, Mosby Elsevier, 2008, 1161-1182

2. Karn CM, Socinski MA, Fletcher JA, Corson JM, Craighead JE: Cardiac synovial sarcoma with translocation $(\mathrm{X} ; 18)$ associated with asbestos exposure. Cancer 1994, 73:74-78

3. Zeren H, Moran CA, Suster S, Fishback NF, Koss MN: Primary pulmonary sarcomas with features of monophasic synovial sarcomas. A clinicopathological, immunohistochemical and ultrastructural study of 25 cases. Hum Pathol 1995, 26: 474-480
4. Helliwell TR, King AP, Raraty M, Wittram C, Morris AI, Myint S, Hershman MJ: Biphasic synovial sarcoma in the small intestinal mesentery. Cancer 1995, 75: 2862-2866

5. Massarelli G, Tanda F, Salis B: Synovial sarcoma of the soft palate: Report of a case. Hum Pathol 1978, 9: 341-345

6. Eusebi V, Russomanno E: Case of synovial sarcoma localized in the retro peritoneum. Arch Ital Anat Istol Patol 1970, 43:260-270

7. Shmookler BM: Retroperitoneal synovial sarcoma. A report of four cases. Am J Clin Pathol 1982, 77: 686-691

8. Scheithauer BW, Amrami KK, Folpe AL, Silva AI, Edgar MA, Woodruff JM, Levi AD, Spinner RJ: Synovial sarcoma of nerve. Hum Pathol 2011, 42: 568-577

9. O'Connel JX, Browne L, Gropper PT, Berean KW: Intraneural biphasic synovial sarcoma: an alternative "glandular" tumor of peripheral nerve. Mod Pathol 1996, 9: 738-741

10. Lipira AB, Kasukurthi R, Ray W, Pruzansky ME, Mackinnon $S E$ : Intraneural synovial sarcoma of median nerve. Rare Tumors 2010, 2: e32

11. Amary MFC, Berisha F, Del Carlo Bernardi F, Herbert A, James M, Reis-Filho JS, Fisher C, Nicholson AG, Tirabosco R, Diss TC, Flanagan AM: Detection of SS18-SSX fusion transcripts in formalin-fixed paraffin-embedded neoplasm: analysis of conventional RT-PCR, qRT-PCR and dual color FISH as diagnostic tools for synovial sarcoma. Mod Pathol 2007, 20: 482-496

12. Fisher C: Synovial Sarcoma. Ann Diagn Pathol 1998, 2:401-421

13. Woodruff JM Christensen WN: Glandular peripheral nerve sheath tumors. Cancer 1993, 72:3618-3628

14. Christensen WN, Strong EW, Bains MS, Woodruff JM: Neuroendocrine differentation in the glandular peripheral nerve sheath tumor. Pathologic distinction from the biphasic synovial sarcoma with glands. Am J Surg Pathol 1988, 12:417-426

15. Guillou L, Coindre JM, Gallagher G, Terrier P, Gebhard S, de Saint Aubain Somerhausen N, Michels JJ, Jundt G, Vince DR, Collin F, Trassard M, Le Doussal V, Benhattar J: Detection of synovial sarcoma translocation $\mathrm{t}(\mathrm{X} ; 18)$ (SYT; SSX) in paraffinembedded tissues using reverse transcriptase-polymerase chain reaction: a reliable and powerful diagnostic tool for pathologist. A molecular analysis of 221 mesenchimal tumors fixed in different fixatives. Hum Pathol 2001, 32:105-112

16. Perry A, Kunz SN, Fuller CE, Banerjee R, Marley EF, Liapis H, Watson MG, Gutmann DH: Differential NF1, p16 and EGFR patterns by interphase cytogenetic (FISH) in malignant peripheral nerve sheath tumor (MPNST) and morphologically similar spindle cell neoplasms. J Neuropathol Exp Neuro 2002, 61:702-709 